\title{
Pengaruh Pertumbuhan Ekonomi Terhadap Tingkat Kesejahteraan Masyarakat Kecamatan Selong Kabupaten Lombok Timur - Nusa Tenggara Barat Menggunakan Algoritma Naive Bayes
}

\author{
Yahya ${ }^{*}$, Hariman Bahtiar² \\ 1,2 Program Studi Sistem Informasi, Universitas Hamzanwadi \\ *ayhay7078@gmail.com
}

\begin{abstract}
Abstrak
Sustainable Development Goals (SDGs) merupakan salah satu program dunia untuk mengatasi permasalahan beberapa hal yang menjadi issue dunia saat ini. Isu-isu dunia yang ingin ditangani antara lain: menghilangkan kemiskinan, hapus kelaparan, membangun kesehatan dan kesejahteraan yang baik, memberikan pendidikan berkualitas, menegakkan kesetaraan gender, tingkatkan air bersih dan sanitasi, tumbuhkan energi yang terjangkau dan bersih, ciptakan pekerjaan yang layak dan pertumbuhan ekonomi, tingkatkan industri, inovasi, dan infrastruktur, kurangi ketimpangan, memobilisasi kota dan komunitas berkelanjutan, mempengaruhi konsumsi dan produksi yang bertanggung jawab, atur aksi iklim, kembangkan hidup di bawah air, maju kehidupan di darat, menjamin kedamaian, keadilan, dan lembaga kuat, bangun kemitraan untuk mencapai tujuan. Tujuh belas komponen yang hendak dituntaskan menyeluruh di dunia, direncanakan tercapai target pada tahun 2030. Semua komponen yang menjadi problem dunia, akan dijadikan sebagai bagian yang akan menjadi target dalam penelitian ini. Salah satu yang menjadi fokus penelitian adalah komponen ekonomi. Data yang diperoleh di Kecamatan Selong, khususnya komponen ekonomi akan dikelola dan diolah menggunakan algoritma Naive Bayes. Setelah dilakukan pengolahan data menggunakan algoritma Naive Bayes, diperoleh nilai tingkat akurasi kedekatan dengan keadaan yang sebenarnya sebesar $93,45 \%$. Dari data yang diperoleh $93,45 \%$ atau $0,9345 x$ jumlah data $(\mathrm{kk})=0,9345 \times 1130 \mathrm{kk}=1056 \mathrm{kk}$ yang menunjukkan masyarakatnya sejahtera dan 6,55\% x $1130=$ $74 \mathrm{kk}$ yang menyatakan masyarakat yang tidak sejahtera dan dapat dijadikan sebagai acuan dalam pengentasan kemiskinan melalui program yang sudah dicanangkan oleh pemerintah.
\end{abstract}

Kata Kunci : Ekonomi, Naive Bayes, SDGs

\begin{abstract}
Sustainable Development Goals (SDGs) is one of the world's programs to overcome several problems that are currently the world's issues. The world's issues that want to be addressed include: eliminating poverty, eliminating hunger, building good health and well-being, providing quality education, enforcing gender equality, improving clean water and sanitation, growing affordable and clean energy, creating decent work and growth. economy, improve industry, innovation and infrastructure, reduce inequality, mobilize sustainable cities and communities, influence responsible consumption and production, regulate climate action, promote life under water, advance life on land, ensure peace, justice and strong institutions, build partnerships to achieve goals. The target of seventeen components that will be completed in the world is planned to be achieved in 2030. All components that become world problems will be used as part of the target in this research. One of the research focuses is the economic component. The data obtained in Selong District, especially the economic component, will be managed and processed using the Naive Bayes algorithm. After processing the data using the Naive Bayes algorithm, the accuracy rate of closeness to the real situation is $93.45 \%$. From the data obtained $93.45 \%$ or $0.9345 x$ the amount of data $(k k)=0.9345 \times 1130 \mathrm{kk}=1056$ families which shows the community is prosperous and $6.55 \% \mathrm{x}$ $1130=74$ families which states that people are not prosperous and can used as a reference in poverty alleviation through programs launched by the government.
\end{abstract}

Keywords: Economic, Naive Bayes, SDGs 


\section{Pendahuluan}

Salah satu komponen yang menjadi perhatian SDGs (Sustainable Development Goals) dari 17 komponen perhatian dunia saat ini adalah "Ekonomi". Perekonomian merupakah salah satu indikator tentang berhasil atau tidaknya, sejahtera atau tidaknya suatu masyarakat di suatu wilayah. Semakin tinggi tingkat perekenonomian suatu masyarakat, semakin meningkat kesejahteraan masyarakat tersebut, begitu pula sebaliknya. Sistem perekonomian adalah sistem yang digunakan oleh suatu negara untuk mengalokasikan sumber daya yang dimilikinya baik kepada individu maupun organisasi di negara tersebut. Perbedaan mendasar antara sebuah sistem ekonomi dengan sistem ekonomi lainnya adalah bagaimana cara sistem itu mengatur faktor produksinya. Dalam beberapa sistem, seorang individu boleh memiliki semua faktor produksi. Sementara dalam sistem lainnya, semua faktor tersebut di pegang oleh pemerintah. Kebanyakan sistem ekonomi di dunia berada di antara dua sistem ekstrem tersebut[1]. Selain faktor produksi, sistem ekonomi juga dapat dibedakan dari cara sistem tersebut mengatur produksi dan alokasi. Sebuah perekonomian terencana (plannedeconomies) memberikan hak kepada pemerintah untuk mengatur faktorfaktor produksi dan alokasi hasil produksi. Sementara pada perekonomianpasar (market economic), pasar lah yang mengatur faktorfaktor produksi dan alokasi barang danjasa melalui penawaran dan permintaan[2]. Sistem ekonomi yang telah berjalan dengan baik, akan mampu menjaga kestabilan ekonomi yang pada akhirnya berimbas pada tingkat kesejahteraan masyarakat yang ada di dalamnya. Kestabilan ekonomi akan mampu menjaga tingkat kesejahteraan masyarakatnya dan apabila tingkat kesejahteraan masyarakat dapat di jaga, maka tingkat keamanan dan kenyamanan masyarakat yang ada dialam sistem itu akan terjamin[3]. Pencarian untuk pertumbuhan ekonomi yang stabil dan lingkungan yang berkelanjutan kualitas dengan cepat menjadi isu topikal di antara pemerintah, lembaga internasional dan pemangku kepentingan lain yang tertarik pada pembangunan berkelanjutan[4]. Berawal dari permasalahan tersebut, maka untuk menjawab permasalahan penelitian ini akan memberikan gambaran terhadap pemahaman tentang sejauh mana tingkat perekonomian, mampu memberikan indikasi yang jelas terhadap kesejahteraan. Apakah masyarakat yang berada di wilayah penelitian, sudah termasuk masyarakat yang mapan atau tidak. Jika sudah mapan apa yang harus dilakukan, jika belum mapan apa yang harus dilakukan. 
DOI : 10.29408/jit.v4i1.2981 Link : https://dx.doi.org/10.29408/jit.v4i1.2981

\section{Tinjauan Pustaka}

\subsection{Penelitian terkait}

- Menurut Ade Ayu Winanda dalam penelitiannya yang berjudul "Analisis Pengaruh Infrastruktur Terhadap Pertumbuhan Ekonomi di Kota Bandarlampung" menyimpulkan bahwa (1) Infrastruktur jalan berpengaruh negatif dan signifikan terhadap pertumbuhan ekonomi di Kota Bandarlampung, (2) infrastruktur energi listrik dan air bersih berpengaruh positif dan signifikan terhadap pertumbuhan ekonomi di Kota Bandarlampung (3) infrastruktur yang memiliki pengaruh terbesar terhadap pertumbuhan ekonomi secara berurutan adalah infrastruktur energi listrik, infrastruktur air bersih memiliki pengaruh terbesar kedua dan terakhir adalah infrastruktur panjang jalan yang memiliki pengaruh terhadap pertumbuhan ekonomi[5].

- Menurut Ega Pralin Yolanda dalam penelitiannya yang berjudul "Pengaruh Sikap Dan Norma Subjektif Terhadap Niat Mahasiswa Untuk Bersaing Menghadapi Masyarakat Ekonomi Asean (MEA)" menyimpulkan bahwa sikap dan norma subjektif berpengaruh positif terhadap niat mahasiswa untuk bersaing menghadapi masyarakat Ekonomi ASEAN (MEA)[2].
- Menurut Arli Kartika Eka Paksi dalam penelitiannya yang berjudul "Analisis Faktor-Faktor Yang Mempengaruhi Pertumbuhan Ekonomi Provinsi Lampung" menyimpulkan bahwa Pendapatan Asli Daerah dengan koefisien Regresi -0.000685 memiliki pengaruh yang negatif dan tidak signifikan terhadap pertumbuhan ekonomi Provinsi Lampung. Tenaga kerja dengan koefisien 3.245693 memiliki pengaruh yang positif dan signifikan terhadap pertumbuhan ekonomi Provinsi Lampung. Variabel Tingkat pendidikan dengan koefisien 488.4898 memiliki pengaruh yang positif dan signifikan terhadap pertumbuhan ekonomi Provinsi Lampung dan Net ekspor dengan koefisien 0.004485 memiliki pengaruh yang positif dan signifikan terhadap pertumbuhan ekonomi Provinsi Lampung[6].

- Menurut "Yongheng Yang" dalam artikelnya yang berjudul "Hotspot diagnosis for solar photovoltaic modules using a Naive Bayes classifier" menyimpulkan bahwa "To achieve so, the texture and histogram of gradient (HOG) features of thermal images of PV modules are used for classification. The categorized hotspots are detected by training the machine learning algorithm, i.e., a Naive Bayes (nBayes) classifier. Experimentalresults are performed on a 
DOI : 10.29408/jit.v4i1.2981 Link : https://dx.doi.org/10.29408/jit.v4i1.2981

42.24-kWp PV system, which demonstrates that a mean recognition rate of around $94.1 \%$ is achieved for the set of 375 samples ${ }^{[7]}$

- Menurut Yupi Kuspandi Putra adalam artikelnya yang berjudul "Perbandingan Algoritma Naive Bayes dan Naive Bayes Berbasis PSO untuk Analisis Kredit pada PT. BPR Syariah Paokmotong", setelah melakukan pengujian dengan model algoritma Naive Bayes sebesar $71.00 \%$, sedangkan dengan model Algoritma Naive Bayes berbasis Particle Swarm Optimization menghasilkan nilai akurasi yang lebih tinggi yaitu $88.51 \%$ dibandingkan dengan model algoritma Naive Bayes. Dari hasil tersebut didapatkan selisih antara kedua model yaitu $17.51 \%[8]$.

- Menurut Muhammad Wasil, Mahfuz dalam penelitiannya yang berjudul "Analisis Persepsi Masyarakat Terhadap Kinerja Aparatur Desa Dalam Meningkatkan Pelayanan Publik Di Desa Lenek Lauk Menggunakan Metode Naive Bayes" menghasilkan kesimpulan bahwa penelitian dilakukan dengan Metode algoritma naïve bayes, berfungsi untuk melihat tingkat akurasinya. Pengukuran dengan algoritma naïve bayes menghasilkan akurasi $92.26 \%$ dan nilai AUC pada Kurva ROC adalah sebanyak $0.924[9]$.

\subsection{Landasan Teori}

1. Pengertian Penerapan

- Menurut kamus besar bahasa Indonesia (KBBI), pengertian penerapan adalah perbuatan menerapkan, sedangkan menurut beberapa ahli, penerapan adalah suatu perbuatan mempraktekkan suatu teori, metode, dan hal lain untuk mencapai tujuan tertentu dan untuk suatu kepentingan yang diinginkan oleh suatu kelompok atau golongan yang telah terencana atau tersusun sebelumnya[10].

- Menurut Usman menyatakan : penerapan (implementasi) adalah bermuara pada aktivitas, aksi, tindakan, atau adanya mekanisme suatu sistem. Implementasi bukan sekedar aktivitas, tetapi suatu kegiatan yang terencana dan untuk mencapai tujuan kegiatan.

- Menurut Setiawan, penerapan (implementasi) adalah perluasan aktivitas yang saling menyesuaikan proses interaksi antara tujuan dan tindakan untuk mencapainya serta memerlukan jaringan pelaksana, birokrasi yang efektif.

\section{Definisi Data}

Menurut Chitrakant Banchhor, Dr. N. Srinivasu dalam artikelnya mengatakan bahwa data besar semakin banyak digunakan di berbagai bidang: seperti industri, transaksi keuangan, kedokteran, dan sebagainya, karena dapat 
DOI : 10.29408/jit.v4i1.2981 Link : https://dx.doi.org/10.29408/jit.v4i1.2981

menangani tantangan dalam memproses data dalam jumlah besar. Salah satu teknik penambangan data yang digunakan secara luas dan efektif untuk mengklasifikasikan data besar adalah model MapReduce[11] Untuk membuat prediksi akurasi, perlu dilakukan pengelompokan sampel yang cukup yang dikumpulkan dari berbagai sumber. Privasi dan masalah keamanan informasi pribadi muncul dalam beberapa tahun terakhir, yaitu, pemilik data dapat dengan keras memungkinkan entitas yang tidak dipercaya untuk mendapatkan akses ke data sensitif mereka, yang membatasi sentralisasi trainer dari kumpulan data sampel[12].

\section{Algoritma Klasifikasi}

Masalah mengklasifikasikan data adalah topik populer dalam pembelajaran mesin dan statistik. Klasifikasi adalah untuk mengidentifikasi untuk kategori apa observasi baru tersebut didasarkan pada set data. Metode heuristik konvensional, seperti pengklasifikasi Naive Bayes telah banyak digunakan dalam banyak aplikasi[13]

\section{Naive Bayes}

Naive Bayes (NB) adalah salah satu dari 10 algoritma penambangan data teratas. Namun, asumsi independensi kondisional jarang berlaku dalam aplikasi dunia nyata. Untuk mengurangi asumsi ini, banyak pendekatan pembobotan atribut telah diusulkan. Namun, beberapa di antaranya secara simultan memperhatikan granularitas horizontal nilai atribut dan granularitas vertikal label kelas[14]. Naive Bayes Classifier adalah algoritma yang efisien dan efektif untuk pembelajaran mesin dan penambangan data. Berbasiskan Naive Bayes Classifier pada kombinasi Bayes Theorem dan atribut independensi anggapan. Naive Bayes Classifier didasarkan pada asumsi yang disederhanakan nilai-nilai atribut independen secara kondisional, dengan asumsi dari nilai target yang diberikan [15]

\section{Metode Penelitian}

\subsection{Metode}

Untuk mendapatkan informasi yang dibutuhkan serta jelas, penulisan dilakukan dengan cara :

- Observasi

Dilakukan dengan mengumpulkan data dari mengamati secara langsung di lokasi penelitian yaitu masyarakat kecamatan selong yang diambil secara random.

- Wawancara

Melakukan tanya jawab dengan masyarakat Kecamatan Selong menggunakan lembar interview yang dimasukkan ke dalam system yaitu aplikasi KKN Tematik Desa Gemilang tahun 2019.

- Studi Pustaka

Pengumpulan informasi yang dibutuhkan dilakukan dengan mencari referensi- 
DOI : 10.29408/jit.v4i1.2981 Link : https://dx.doi.org/10.29408/jit.v4i1.2981

referensi yang berkaitan dengan kasus yang dibahas melalui buku dan internet

\subsection{Tahapan Penelitian}

Untuk mencapai tujuan yang diinginkan dalam penelitian, dilakukan beberapa tahapan penelitian antara lain :

- Pengambilan data.

Data yang digunakan adalah data private yang diambil dari hasil pendataan KKN Tematik Desa Gemilang Universitas Hamzanwadi tahun 2019.

- Pengolahan data.

Data yang diperoleh dari pendataan KKN Tematik Desa Gemilang Universitas Hamzanwadi, diolah menggunakan tools Rapid Miner dengan menerapkan Algoritma Naive Bayes, dilakukan 5-10 kali eksperimen dengan menggunakan K-Vold validation yang berbeda-beda sebagai bahan untuk menganalisis dan pengambilan keputusan dalam penelitian ini.

- Rekapitulasi data

Data yang diperoleh dari hasil eksperimen, dikumpulkan dalam satu tabel khusus yaitu tabel rekapitulasi hasil eksperimen.

\section{- Analisa}

Analisa yang dimaksud dalam penelitian ini adalah analisa terhadap hasil pengolahan data dari beberapa kali melakukan percobaan.
Penarikan kesimpulan

Penarikan kesimpulan dilakukan berdasarkan hasil proses pengolahan dan analisa data. Hal ini penting dilakukan untuk menentukan langkah selanjutnya yang perlu dilakukan dan sebagai bahan referensi pada penelitian berikutnya dengan menggunakan algoritma yang berbeda.

\section{Hasil dan Pembahasan}

\subsection{Hasil Percobaan}

Dari hasil pengolahan data yang dilakukan menggunakan Algoritma Naive Bayes, diperoleh beberapa temuan antara lain:

- Percobaan dilakukan sebanyak 6 kali dengan menggunakan K-Fold Validation yang berbeda-beda. Hasil yang diperoleh menggunakan K-Fold Validation yang berbeda-beda adalah nilai akurasi yang berbeda bahkan nilainya cenderung berubahubah dan tidak menunjukkan bahwa semakin besar K-Fold Validation, maka nilai akurasinya semakin besar.

- Nilai akurasi tertinggi diperoleh pada percobaan menggunakan K-Fold Validation 10 dengan nilai akurasi $93,45 \%$.

- Hasil dari pengolahan data yang dilakukan menggunakan algoritma Naïve Bayes dan telah diujicobakan menggunakan 6 kali percobaan, telah ditunjukkan pada tabel rekapitulasi data tabel di bawah ini : 
DOI : 10.29408/jit.v4i1.2981 Link : https://dx.doi.org/10.29408/jit.v4i1.2981

Tabel 1. Rekapitulasi Hasil Pengolahan Data

\begin{tabular}{lll}
\hline No. & K-Fold Validation & Akurasi \\
\hline $\mathbf{1}$ & K-Fold Validation 5 & $92.92 \%$ \\
$\mathbf{2}$ & K- Fold Validation 6 & $92.83 \%$ \\
$\mathbf{3}$ & K- Fold Validation 7 & $92.39 \%$ \\
$\mathbf{4}$ & K- Fold Validation 8 & $93.01 \%$ \\
$\mathbf{5}$ & K- Fold Validation 9 & $92.65 \%$ \\
$\mathbf{6}$ & K- Fold Validation 10 & $93.45 \%$ \\
\hline
\end{tabular}

\subsection{Pembahasan}

Hasil pengolahan data yang digambarkan pada table di atas dapat dijelaskan sebagai berikut :

- akurasi 92,92\% artinya jumlah masyarakat yang tergolong sejahtera adalah 0,9292 $\mathrm{x}$ $1130=1050 \mathrm{kk}$ dan $0,0708 \times 1130=80 \mathrm{kk}$ yang tergolong tidak sejahtera.

- akurasi 92,83\% artinya jumlah masyarakat yang tergolong sejahtera adalah $0,9283 \times$ $1130=1049 \mathrm{kk}$ dan $0,0717 \times 1130=81 \mathrm{kk}$ yang tergolong tidak sejahtera.

- akurasi 92,39\% artinya jumlah masyarakat yang tergolong sejahtera adalah $0,9239 \times$ $1130=1044 \mathrm{kk}$ dan $0,0761 \times 1130=86 \mathrm{kk}$ yang tergolong tidak sejahtera.

- akurasi 93,01\% artinya jumlah masyarakat yang tergolong sejahtera adalah $0,9301 \mathrm{x}$ $1130=1051 \mathrm{kk}$ dan 0,0699 x $1130=79 \mathrm{kk}$ yang tergolong tidak sejahtera.

- akurasi 92,65\% artinya jumlah masyarakat yang tergolong sejahtera adalah $0,9265 \times$ $1130=1047 \mathrm{kk}$ dan $0,0735 \times 1130=83 \mathrm{kk}$ yang tergolong tidak sejahtera. akurasi
$93,45 \%$ artinya jumlah masyarakat yang tergolong sejahtera adalah $0,9345 \times 1130=$ $1056 \mathrm{kk}$ dan $0,0655 \times 1130=74$ kk yang tergolong tidak sejahtera.

\section{Kesimpulan}

Dari hasil penelitian yang dilakukan menggunakan data ekonomi masyarakat Kecamatan Selong menggunakan Algoritma Naive Bayes, dapat disimpulkan bahwa masyarakat Kecamatan Selong merupakan masyarakat yang tergolong masyarakat yang sudah sejahtera apabila dilihat dari faktor ekonomi, dengan tingkat akurasi kedekatan dengan keadaan yang sebenarnya sebesar $93,45 \%$. Dari data yang diperoleh $93,45 \%$ atau $0,9345 \times$ jumlah data $(k \mathrm{k})=0,9345 \times 1130 \mathrm{kk}=$ 1056 kk yang menunjukkan masyarakatnya sejahtera dan $6,55 \% \times 1130=74 \mathrm{kk}$ yang menyatakan masyarakat yang tidak sejahtera dan dapat dijadikan sebagai acuan dalam pengentasan kemiskinan melalui program yang sudah dicanangkan oleh pemerintah.

\section{Daftar Pustaka}

[1] European Environment Agency (EEA), "PENGARUH SIKAP DAN NORMA SUBJEKTIF TERHADAP NIAT MAHASISWA UNTUK BERSAING MENGHADAPI MASYARAKAT EKONOMI ASEAN (MEA)," vol. 53, no. 9, pp. 1689 
DOI : 10.29408/jit.v4i1.2981 Link : https://dx.doi.org/10.29408/jit.v4i1.2981

1699, 2019, doi: 10.1017/CBO9781107415324.004.

[2] A. A. Winanda, "Analisis Faktor-Faktor Yang Mempengaruhi Pertumbuhan Ekonomi Provinsi Lampung," no. 2, pp. 23, 2016.

[3] A. K. E. Paksi, "Analisis Faktor-Faktor yang Memepengaruhi Pertumbuhan Ekonomi Provinsi Lampung," Skripsi Fak. Ekon. dan Bisnis Univ. Lampung, pp. 1-84, 2016, [Online]. Available: http://digilib.unila.ac.id/22763/3/SKRIPSI TANPA BAB PEMBAHASAN.pdf.

[4] Л. М. Мещерякова and Л. С. Понтак, "Analysis of Infrastructure Influence to Economic Growth in Bandarlampung," no. 2, pp. 2-3.

[5] A. K. E. Paksi, "Analisis Faktor-Faktor Yang Mempengaruhi Pertumbuhan Ekonomi Provinsi Lampung," 2016.

[6] E. P. Yolanda, "Pengaruh Sikap Dan Norma Subjektif Terhadap Niat Mahasiswa Untuk Bersaing Menghadapi Masyarakat Ekonomi Asean (Mea)," 2016.

[7] K. A. K. Niazi, W. Akhtar, H. A. Khan, Y. Yang, and S. Athar, "Hotspot diagnosis for solar photovoltaic modules using a Naive Bayes classifier," Sol. Energy, vol. 190, no. August, pp. 34-43, 2019, doi: 10.1016/j.solener.2019.07.063.
[8] Y. K. Putra and M. Sadali, "Perbandingan Algoritma Naive Bayes dan Naive Bayes Berbasis PSO untuk Analisis Kredit pada PT. BPR Syariah Paokmotong," Infotek, vol. 3, no. 2, p. 2019, 2020, doi: 10.22201/fq.18708404e.2004.3.66178.

[9] M. Wasil, "Infotek: Jurnal Informatika dan Teknologi Analisis Persepsi Masyarakat Terhadap Kinerja Aparatur Desa Dalam Meningkatkan Pelayanan Publik Di Desa Lenek Lauk Menggunakan Metode Naive Bayes Pelayanan publik adalah kegiatan atau rangkaian kegiatan dalam ran," vol. 3 , no. 2, pp. 140-146, 2020.

[10] R. Setiawan and N. Tes, "PENERAPAN DATA MINING MENGGUNAKAN ALGORITMA K-MEANS CLUSTERING UNTUK MENENTUKAN STRATEGI PROMOSI MAHASISWA BARU ( Studi Kasus : Politeknik LP3I Jakarta )," vol. 3, no. 1, pp. 76-92, 2016.

[11] C. Banchhor and N. Srinivasu, "Jo urn a," Data Knowl. Eng., p. 101788, 2019, doi: 10.1016/j.datak.2019.101788.

[12] R. Waheed, S. Sarwar, and C. Wei, "The survey of economic growth, energy consumption and carbon emission," Energy Reports, vol. 5, pp. 1103-1115, 2019, doi: 10.1016/j.egyr.2019.07.006.

[13] Y. Zhang and L. Sakhanenko, "The naive Bayes classifier for functional data," Stat. 
DOI : 10.29408/jit.v4i1.2981 Link : https://dx.doi.org/10.29408/jit.v4i1.2981

Probab. Lett., vol. 152, pp. 137-146, 2019, doi: 10.1016/j.spl.2019.04.017.

[14] H. Zhang, L. Jiang, and L. Yu, "Classspecific attribute value weighting for Naive Bayes," Inf. Sci. (Ny)., vol. 508, pp. 260274, 2020, doi: 10.1016/j.ins.2019.08.071.
[15] M. Andrejiova and A. Grincova, "Classi fi cation of impact damage on a rubber-textile conveyor belt using Naïve-Bayes methodology," Wear, vol. 414-415, no. August, pp. 59-67, 2018, doi: 10.1016/j.wear.2018.08.001. 